\title{
ASSESSMENT OF ENVIRONMENTAL POLLUTION WITH METALS IN SOME INDUSTRIAL REGIONS OF KOSOVO USING CHICKEN (Gallus gallus domesticus) BREAST FEATHERS
}

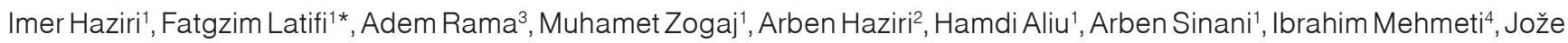
Starič ${ }^{5}$

${ }^{1}$ Faculty of Agriculture and Veterinary, Department of Veterinary Medicine, ${ }^{2}$ Faculty of Natural Science, Department of Chemistry, Universitety of Prishtina, 10000 Prishtina, Kosovo, ${ }^{3}$ Higher Colleges of Technology Sharjah Mans College, Sharjah, United Arab Emirates, ${ }^{4}$ Department of Chemistry Biotechnology and Food Sciences, Norwegian University of Life Sciences (NMBU), Ås, Norway, ${ }^{5}$ Faculty of Veterinary Medicine, University of Lubljana, 1000 Ljubljana, Slovenia

*Corresponding author, E-mail: fatgzim.latifi@uni-pr.edu

\begin{abstract}
The aim of this study was to assess the presence of metals in three regions of Kosovo using chicken (Gallus gallus domesticus) breast feathers collected from the industrial regions of Mitrovica and Obiliq and the non-industrial region of Dragash. This study was carried out from September to November 2016, and feathers were collected from 90 individual domestic chickens housed as free range. The concentrations of metals in the chicken feathers were determined with atomic absorption spectrometry (AAS). The range of average measured concentrations of metals $\left(\mu \mathrm{g} \mathrm{g}^{-1}\right)$ in examined regions were: $\mathrm{Zn} 109-131, \mathrm{Mn} 6.17-31.30$, Cu 22.1-27.2, Cr 5.09-19.0, Ni 12.3-15.8, Pb <0.0945-15.5, Cd 11.1-12.3 and As <0.099-7.44. The highest average levels of metals were determined in regions ( $\mathrm{mg} \mathrm{g}^{-1}$ ): Dragash: Zn 131, Cu 27.2, Mn 31.3, Cr 19.0, Ni 15.8; Mitrovica As 7.44, Cd 12.3, Pb 15.5. High statistically significant differences ( $p<0.001$ ) were found between the three regions for $\mathrm{Pb}, \mathrm{As}, \mathrm{Mn}$, and $\mathrm{Cr}$ content. There were no significant differences ( $p>0.05$ ) between the Mitrovica and Obiliq regions in terms of Zn content, Mitrovica and Dragash in terms of Cu or between the Obiliq and Dragash regions in terms of $C d$ content. These results should concern the environmental agencies in Kosovo and encourage them to take concrete steps by periodically checking these pollutants in these two industrial regions. Based on our results, we recommend that programmes for monitoring environmental pollution from metals could use chicken feathers as an important and valuable test material.
\end{abstract}

Key words: trace metals; AAS; chicken feathers; environmental pollution; Kosovo

\section{Introduction}

In recent years, the increase in industrial activities has had an impact on environmental pollution, which has shifted the equilibrium of the global ecosystem $(1,2)$. Among the pollutants that contribute to this problem are non-essential metals, such as $\mathrm{Pb}, \mathrm{Hg}, \mathrm{Cd}$, and $\mathrm{As}(3)$.

Received: 30 March 2018

Accepted for publication: 3 July 2019
Non-essential metals are likely to enter a living organism through the food chain (4). These metals can cause various health problems in the organism by weakening the immune system, causing oxidative stress (5), effecting the blood biochemical parameters, reducing reproduction capabilities, reducing body weight, increasing heart diseases, and leading to the manifestation of different mutations and neoplasms $(6,7,8,9,10)$.

Bioindication and biomonitoring are forms of monitoring of environmental pollution that help to identify sources of essential and non- 
essential metals as well as their effects on the living world $(11,12)$. Using these methods, several authors have investigated various flora and fauna such as plants (13), insects (14), and fish $(15,16)$ that could serve as bioindicators $(17)$. Birds have been recognized since the 1960s as potential bioindicators of environmental pollution (18). With the aim of measuring environmental pollution from metals and their effects on living organisms, researchers have used different materials taken from birds, such as blood, lungs, liver, musculature, and the gizzard $(19,20,21,22$, 23). Fairly reliable results for the measurement of environmental contamination with metals have been obtained using avian feathers $(24,25,26$, 27). Specifically, metals present in the feathers reflect their concentration in the circulating blood during the 2-3 weeks of feather formation, which in turn represents both exposure and mobilization from internal tissues $(28,29)$. Thus, feathers serve as an archive of metal exposure during feather formation (30).

Avian feathers have been confirmed to be a suitable material for measuring effective contamination of metals in the environment (31). The concentration of metals in feathers has been shown to be much higher than that in other organs because feathers contain the protein keratin, which is a protein that metals tend to bind. Also, feathers are considered one of the best ways to eliminate metals from a chicken's body $(32,31,33)$.

Concerning environmental pollution with metals, different researchers have analysed different samples in different regions of Kosovo, such as soils (34), earthworms (35), sparrows (36) and the results obtained from these surveys show multiple levels of non-essential metals compared to unpolluted areas. Based on this research, the most polluted region in terms of metals was the Mitrovica region and its surroundings, which is the most polluted region in all of Europe. This result was also confirmed by international agencies (37). Contributing significantly to this pollution in the region of Mitrovica was the $\mathrm{Pb}$ and $\mathrm{Zn}$ smelter, from which $\mathrm{Pb}$ was produced at approximately 730 tons per year at the end of 1990s (38). The $\mathrm{Pb}$ and $\mathrm{Zn}$ smelter was closed in August 2000 by the NATO military forces (39). However, numerous studies have been carried out in this region after the closure of the foundry, with the results showing alarming levels of metals ( $\mathrm{Pb}, \mathrm{As}, \mathrm{Cd}, \mathrm{Zn}$, etc.) and their effects on animals and humans $(36,39)$. In the Obiliq region, there are two thermal power stations, as well as coal mines, and investigations revealed that in the grey matter that flows from these power plants, the metals were present in very high levels (40). Dragash is a region that does not contain any industrial factory; therefore, we used this region as a control.

Based on the above findings, we conducted a survey to assess the presence of metals in chicken feathers obtained from the following three different regions of Kosovo: Mitrovica, Obiliq and Dragash.

\section{Materials and methods}

\section{Study area}

The samples were collected from three study regions (areas), including Mitrovica, Obiliq and Dragash, as shown in Figure 1.

The Mitrovica region is located in the northern part of Kosovo, and it has the largest metallurgic and mining complex (Trepca) in Europe for the extraction of $\mathrm{Pb}, \mathrm{Cd}$ and $\mathrm{Zn}$. Many industrial plants existed in the complex, such as a $\mathrm{Pb}$ smelter, fertilizer production plant, refinery, battery factory, Zn electrolysis facility and a sulfuric acid plant. Significant amounts of metal pollutants have been released into the surrounding area, including populated residential areas, and these pollutants have been associated with human health risks (41).

Obiliqi is an industrial region that is located in the centre part of Kosovo. This region contains two thermal power stations, "Kosova A" and "Kosova B", as well as coal mines for coal extraction. Coal contains the metals $\mathrm{Pb}, \mathrm{Hg}, \mathrm{Ni}, \mathrm{Cd}$, As, and others (42), and the combustion from coal-based power plants is one of the most important processes contributing to pollution of the environment and groundwater because of the air ash distribution that contains many metals (43).

Dragash is a non-industrial region and is located in the southern part of Kosovo near Sharr Mountain. Geological analysis has shown that Sharr Mountain is very rich in metals, such as Fe, $\mathrm{Cu}, \mathrm{Mn}, \mathrm{Cr}$, and $\mathrm{Zn}$ (44). These metals can enter living organisms through the food chain (4). 
Figure 1: Map of Republic of Kosovo location of Mitrovica, Obiliq and Dragash

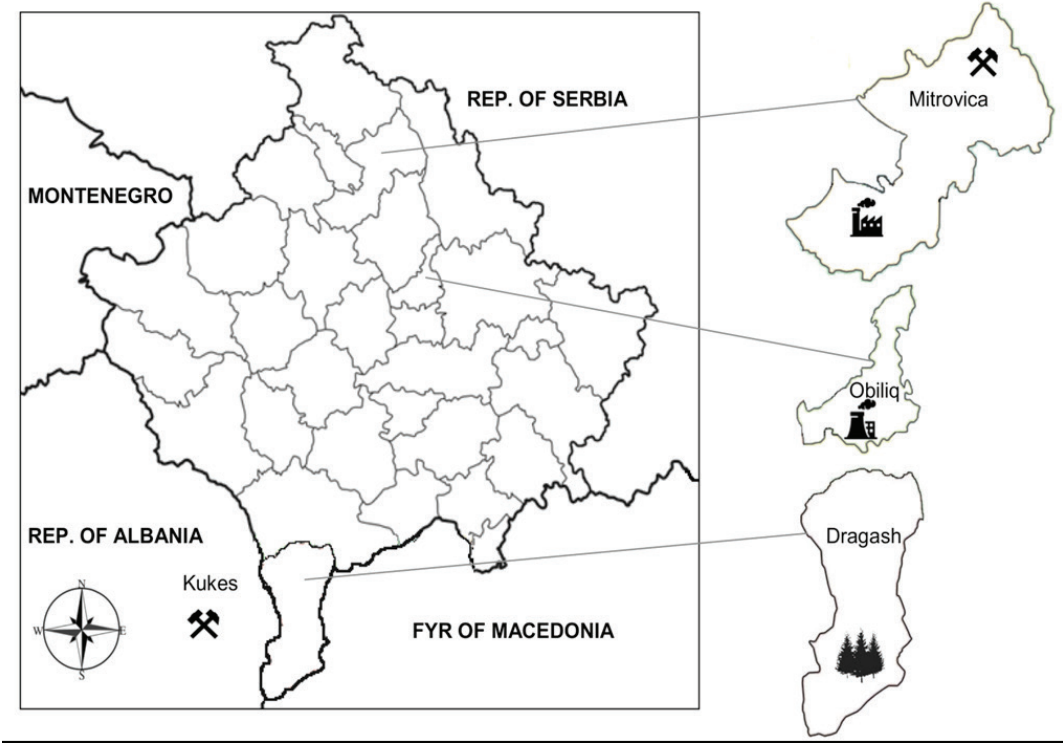

\section{Sampling plan and analytical procedures}

The study was performed according to ethical guidelines of the Department of Veterinary Medicine, University of Pristina. In this research backyard chickens Gallus gallus domesticus were used, kept in these three regions. Breast feathers were collected by cutting them off with scissors at the skin level for the assessment of metal contamination from chicken which were grown in industrial regions of Mitrovica and Obiliq and the non-industrial region of Dragash. Three farms were sampled in each region and 10 chickens were selected from each farm. The number of chickens was 30 individuals from each region, a total of 90 domestic chickens. All of them were between 1-2 years old, mix breed, females and hatched on selected farms. All collected feathers were dark grey to black. The chickens were kept as free range (out roaming the day and housed at night), and they were fed mostly with maize grains from the same region along with feed they browsed when roaming freely on farm holding. The samples were sent to the laboratory for metal analysis at the Faculty of Agriculture and Veterinary, University of Pristine, Kosovo. Feathers were weighed, stored in plastic bags, labelled for later identification, and kept at $-20{ }^{\circ} \mathrm{C}$ until they were dissected and analysed.

All feathers were washed three times with acetone followed by deionized water, and then the feathers were dried in an oven at $70{ }^{\circ} \mathrm{C}$ for 24 hours. Additionally, all laboratory dishes were cleaned with concentrated sulfuric acid, then washed with distilled water and dried in an oven. The feather samples $(0.5 \mathrm{~g})$ were digested with 70 $\%$ nitric acid (Sigma Aldrich, Merck, Darmstadt, Germany) and $30 \%$ hydrogen peroxide (Sigma Aldrich, Merck, Darmstadt, Germany) at room temperature overnight. The next day, the samples were completely digested in a digestion unit DK heating digester (VELP Scientifica, Usmate (MB), Italy) at $150{ }^{\circ} \mathrm{C}$ for 4 hours until the solutions became clear $(45,46)$. After cooling, the solution volume was brought up to $50 \mathrm{~mL}$ using deionized water. Following digestion, the solutions were filtered through $0.45 \mu \mathrm{m}$ acid-resistant filter paper Whatman (Sigma Aldrich, Merck, Darmstadt, Germany). The concentrations of metals in chicken breast feathers were measured with an atomic absorption spectrometer (AAS) (MSeries, Thermo, Cambridge, UK) using the flame method. Very low concentrations of $\mathrm{Cd}$ and $\mathrm{Pb}$ in extracts were determined using a graphite furnace atomic absorption spectrometry (GFAAS), whereas As was determined through hydride generation atomic absorption spectrometry (HGAAS). For quality assurance, internal reference materials (i.e., cow liver and spleen) were used for measuring metals. The recovery rates for the internal reference materials were between 78.5 - $107.3 \%$, with a low relative standard deviation (RSD) of $13 \%$. For all analysed metals, the limits of detection

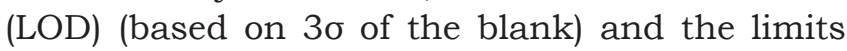

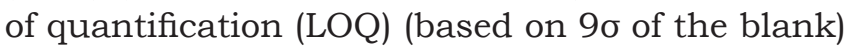
given in Table 1 were calculated based on the DIN32645 calculation procedure (47). 
Table 1: Limits of detection and quantification ( $\mu g \mathrm{~g}-1)$ for analysed metals for chicken feathers samples at given wavelengths within AAS analysis

\begin{tabular}{cccc}
\hline \multirow{2}{*}{ Element } & $\begin{array}{c}\text { Wavelength } \\
\mathrm{nm}\end{array}$ & $\mu^{-1}$ & Limit of quantification $[9 \sigma]$ \\
\cline { 3 - 4 } $\mathrm{As}$ & 193.7 & 0.033 & $\mu \mathrm{g} \mathrm{g}^{-1}$ \\
$\mathrm{Cd}$ & 228.8 & 0.021 & 0.099 \\
$\mathrm{~Pb}$ & 217 & 0.0315 & 0.063 \\
$\mathrm{Ni}$ & 232 & 0.105 & 0.0945 \\
$\mathrm{Cr}$ & 357.9 & 0.186 & 0.315 \\
$\mathrm{Mn}$ & 279.5 & 0.063 & 0.558 \\
$\mathrm{Cu}$ & 324.8 & 0.108 & 0.189 \\
$\mathrm{Zn}$ & 213.9 & 0.036 & 0.324 \\
\hline
\end{tabular}

Table 2: Average concentration value $(\mathrm{M}) \pm$ standard error of mean (SEM) and concentration range of metals $\left(\mu \mathrm{g} \mathrm{g}^{-1}\right)$ found in the chicken feathers and the differences in metal concentrations between the three regions of Mitrovica, Obiliq and Dragash

\begin{tabular}{|c|c|c|c|c|c|c|}
\hline \multirow[t]{2}{*}{ Elements } & \multirow{2}{*}{$\begin{array}{c}\text { Mitrovica } \\
\mathrm{n} 30\end{array}$} & \multirow{2}{*}{$\begin{array}{c}\begin{array}{c}\text { Obiliq } \\
\text { n } 30\end{array} \\
2 \\
\end{array}$} & \multicolumn{2}{|l|}{$\begin{array}{c}\text { Dragash } \\
\text { n } 30\end{array}$} & \multicolumn{2}{|l|}{ P Value } \\
\hline & & & 3 & $1: 2$ & $1: 3$ & $2: 3$ \\
\hline As & $\begin{array}{l}7.44 \pm 0.33 \\
(6.00-9.99)\end{array}$ & $\begin{array}{l}1.50 \pm 0.01 \\
(1.04-1.88)\end{array}$ & $<0.099 \#$ & $0.000^{* * *}$ & $0.000^{* * *}$ & $0.000^{* * *}$ \\
\hline $\mathrm{Cd}$ & $\begin{array}{l}12.30 \pm 0.47 \\
(10.10-15.69)\end{array}$ & $\begin{array}{l}11.70 \pm 0.12 \\
(9.97-11.82)\end{array}$ & $\begin{array}{l}11.10 \pm 0.12 \\
(10.15-11.80)\end{array}$ & $0.024^{*}$ & $0.043^{*}$ & 0.904 \\
\hline $\mathrm{Pb}$ & $\begin{array}{l}15.50 \pm 0.45 \\
(13.28-17.72)\end{array}$ & $\begin{array}{l}2.50 \pm 0.13 \\
(1.23-2.79)\end{array}$ & $<0.0945 \#$ & $0.000^{* * *}$ & $0.000^{* * *}$ & $0.000^{* * *}$ \\
\hline $\mathrm{Ni}$ & $\begin{array}{l}14.30 \pm 0.55 \\
(11.80-17.75)\end{array}$ & $\begin{array}{l}12.30 \pm 0.38 \\
(10.42-14.58)\end{array}$ & $\begin{array}{l}15.80 \pm 0.58 \\
(12.73-19.26)\end{array}$ & $0.003^{* *}$ & $0.042^{*}$ & $0.000^{* * *}$ \\
\hline $\mathrm{Cr}$ & $\begin{array}{l}11.10 \pm 0.21 \\
(9.43-12.20)\end{array}$ & $\begin{array}{l}5.09 \pm 0.19 \\
(4.10-6.21)\end{array}$ & $\begin{array}{l}19.00 \pm 1.12 \\
(14.02-27.14)\end{array}$ & $0.000 * * *$ & $0.000^{* * *}$ & $0.000 * * *$ \\
\hline $\mathrm{Mn}$ & $\begin{array}{l}15.20 \pm 0.53 \\
(12.74-19.40)\end{array}$ & $\begin{array}{l}6.17 \pm 0.20 \\
(4.97-7.52)\end{array}$ & $\begin{array}{l}31.30 \pm 1.47 \\
(21.39-39.54)\end{array}$ & $0.000^{* * *}$ & $0.000^{* * *}$ & $0.000^{* * *}$ \\
\hline $\mathrm{Cu}$ & $\begin{array}{l}25.00 \pm 0.68 \\
(20.73-28.75)\end{array}$ & $\begin{array}{l}22.10 \pm 0.39 \\
(19.86-23.90)\end{array}$ & $\begin{array}{l}27.20 \pm 1.20 \\
(19.60-32.20)\end{array}$ & $0.001^{* *}$ & 0.072 & $0.001^{* *}$ \\
\hline $\mathrm{Zn}$ & $\begin{array}{l}111.00 \pm 2.36 \\
(97.70-120.75)\end{array}$ & $\begin{array}{l}109.10 \pm 2.70 \\
(99.58-128.90)\end{array}$ & $\begin{array}{l}131.00 \pm 6.54 \\
(102.00-172.38)\end{array}$ & 0.613 & $0.018^{*}$ & $0.001^{* *}$ \\
\hline
\end{tabular}

Note: Significance level: $p<0.05^{*}, p<0.01^{* *}, p<.001^{* * *}$, \# LOQ-limit of quantification 
Figure 2: The average and standard deviation of $\mathrm{As}, \mathrm{Cd}, \mathrm{Pb}, \mathrm{Ni}, \mathrm{Cr}, \mathrm{Mn}, \mathrm{Cu}$ and $\mathrm{Zn}$ in breast chicken feather in the three regions of Kosovo (The sample size is 30 animals for each region presented in the figure)

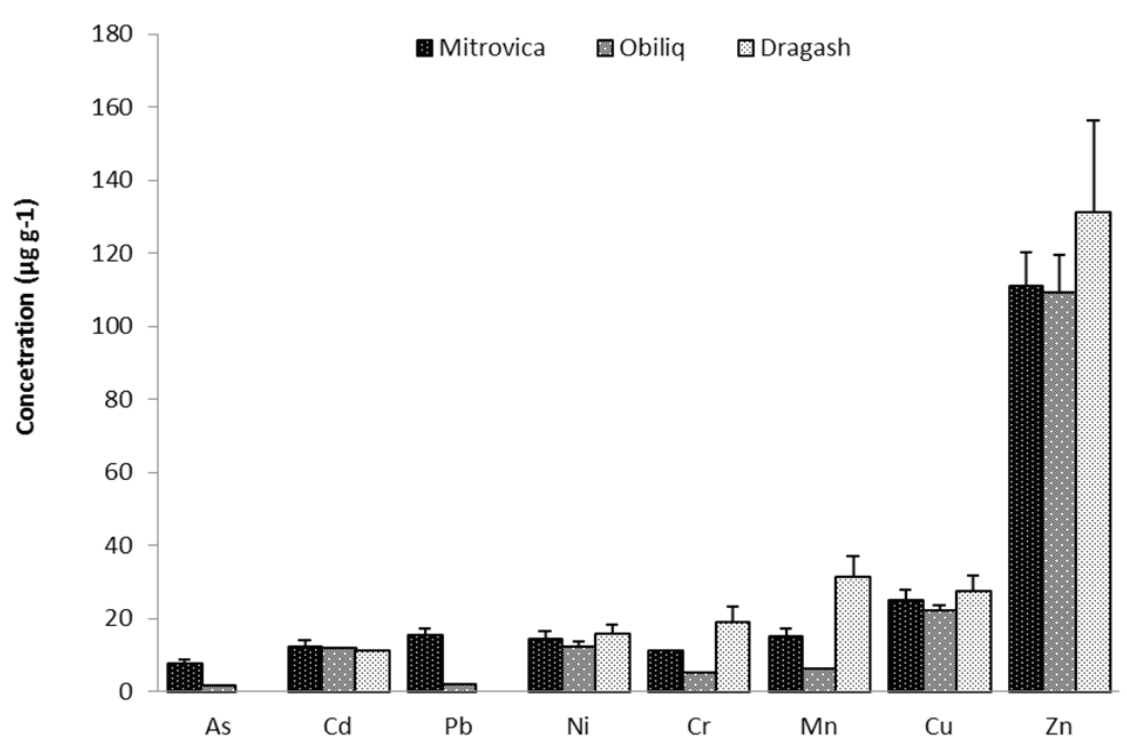

\section{Statistical analyses}

Statistical analyses were performed using the Statistical Package for Social Sciences (SPSS, USA) software, version 21 . The t-test and analysis of variance (ANOVA) were used to assess the differences in metal concentrations between the three regions. The level of significance for the differences was set at $\mathrm{p}<0.05, \mathrm{p}<0.01$ and $\mathrm{p}<0.001$.

\section{Results and discussion}

The descriptive statistics for the metal $(\mathrm{Pb}$, As, $\mathrm{Cd}, \mathrm{Cr}, \mathrm{Mn}, \mathrm{Ni}, \mathrm{Cu}$ and $\mathrm{Zn}$ ) concentrations in chicken feathers from the three regions (Mitrovica, Obiliq and Dragash) determined in this study are shown in Table 2. In a more comprehensive measurement of the quantity of elements in the chicken feathers, we observed the following alignment for almost all the regions: $\mathrm{Zn}>\mathrm{Cu}>\mathrm{Mn}$ $>\mathrm{Ni}>\mathrm{Cr}>\mathrm{Cd}>\mathrm{Pb}>$ As. For better visualization of the differences, the metal concentrations in chicken feathers are presented in Figure 2.

In general, the results from our study showed that there was a difference in the metal concentration in chicken feathers between the three studied regions. Among the metals included in the study, higher significant differences in the concentration of metals between the three regions were observed for $\mathrm{Pb}, \mathrm{As}, \mathrm{Cr}$, and $\mathrm{Mn}(\mathrm{p}<0.001)$.

\section{Concentration profiles and risk to the avian fauna}

\section{Lead}

Significantly higher average $\mathrm{Pb}$ concentration was observed in the Mitrovica region $\left(15.5 \mu \mathrm{g} \mathrm{g}^{-1}\right)$ compared with the Obiliq region $\left(2.5 \mu \mathrm{gg}^{-1}\right)$, whereas the concentration of $\mathrm{Pb}$ in the Dragash region was at a minimum level, below the LOQ value. This high variation in the $\mathrm{Pb}$ concentration shows the real differences in environmental pollution between the three regions. The occurrence of this variation between the regions can be explained due to the presence of the large metallurgic and mining complex (Trepca) in the Mitrovica region, which is also considered to be the main source of environmental pollution. High concentrations of $\mathrm{Pb}$ in chicken feathers have also been reported by other authors from different countries around the world, including South Korea (48) at 3.32-20.8 $\mu \mathrm{g} \mathrm{g}^{-1}$, China (46) at $3.95-13.8 \mu \mathrm{g} \mathrm{g}^{-1}$, and Nigeria (49) at $0.64-1.62 \mu \mathrm{g} \mathrm{g}^{-1}$. The study conducted by Salwa et al. (50) found that the concentration of $\mathrm{Pb}$ in poultry feathers was $0.869 \mu \mathrm{g} \mathrm{g}^{-1}$. Although feathers are connected to the blood circulation, $\mathrm{Pb}$ accumulates in the keratin protein of the feathers (51). A high level of $\mathrm{Pb}$ was also found in human blood samples that were collected for research in the Mitrovica region (52). Indeed, the concentration of $\mathrm{Pb}$ in the blood of humans living in the Mitrovica region was shown to be at a relatively alarming level $\left(3.8 \mu \mathrm{g} \mathrm{dL}^{-1}\right)$ (53). 


\section{Arsenic}

The highest average As concentration was

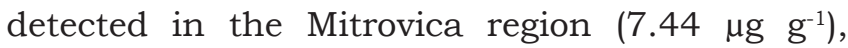
followed by the Obiliq region $\left(1.5 \mu \mathrm{g} \mathrm{g} \mathrm{g}^{-1}\right)$, and no measurable level was observed for the Dragash region. Industrial development, such as mines, is considered to be the major source of air pollution from As (54). Given that a mining complex is situated in the Mitrovica region, the presence of a higher concentration of As was expected for this region compared to the Obiliq and Dragash regions. Other authors have reported similar levels, including values from Belgium (55) at 0.88 - 23.35 $\mu \mathrm{g} \mathrm{g}^{-1}$, Pakistan (56) at $19-21.4 \mu \mathrm{g} \mathrm{g} \mathrm{g}^{-1}$, and Malaysia (50) up to $0.472 \mu \mathrm{g} \mathrm{g} \mathrm{g}^{-1}$. According to Stafilov et al. (57), the concentration of As in soil from the Mitrovica region was $55 \mu \mathrm{g} \mathrm{g} \mathrm{g}^{-1}$.

\section{Chromium}

The highest average concentration of $\mathrm{Cr}$ was found in the Dragash region $\left(19.0 \mu \mathrm{g} \mathrm{g} \mathrm{g}^{-1}\right)$, followed by Mitrovica (11.1 $\mathrm{\mu g} \mathrm{g}^{-1}$ ) and the Obiliq region (5.09 $\left.\mu g \mathrm{~g}^{-1}\right)$. The differences in the $\mathrm{Cr}$ concentration between the regions were found to be statistically significant $(p<0.001)$. The significantly higher concentration of $\mathrm{Cr}$ in the chicken feathers from the region of Dragash could be related to the fact that this region is located near the city of Kukes in Albania, which is considered to be the region with the largest $\mathrm{Cr}$ mine in Europe $(58,59)$. Similar results for the $\mathrm{Cr}$ concentration in feathers have been reported by other studies in different countries around the world, including Malaysia (50) at 2.66 - $4.85 \mu \mathrm{g} \mathrm{g}^{-1}$ and Pakistan (56) at $19-21.1 \mu \mathrm{g} \mathrm{g}^{-1}$.

\section{Manganese}

The results of this study showed that the Dragash region also had the highest average Mn concentration in chicken feathers (31.3 $\mu \mathrm{g} \mathrm{g}^{-1}$ ) compared to Mitrovica (15.2 $\mu \mathrm{g} \mathrm{g}^{-1}$ ) and Obiliq (6.17 $\left.\mu g \mathrm{~g}^{-1}\right)$. The Dragash region is very rich in minerals containing Mn (60). Similar concentrations have been found in the feathers of birds in other studies, including $7.21-65.98 \mu \mathrm{g} \mathrm{g}^{-1}$ (50) and 15.3 - $26.9 \mu \mathrm{g} \mathrm{g} \mathrm{g}^{-1}$ (31). The Mn concentration in the feathers could be related to the concentrations of ingested contaminants as well as to the contents of contaminants in the air (61).

\section{Nickel}

The average concentration of $\mathrm{Ni}$ in chicken feathers in the Mitrovica region was found to be $14.3 \mu \mathrm{g} \mathrm{g}^{-1}$. The highest average concentration of $\mathrm{Ni}$ observed in the Dragash region was $15.8 \mu \mathrm{g}$ $\mathrm{g}^{-1}$, while the lowest concentration was found in the Obiliq region at $12.3 \mu \mathrm{g} \mathrm{g} \mathrm{g}^{-1}$. High statistically significant differences were observed when the Obiliq and Dragash regions were compared $(p<0.001)$. These differences were less dramatic when Mitrovica to Obiliq ( $p<0.01$ ) and Mitrovica to the Dragash region $(\mathrm{p}<0.05)$ were compared. From the results of Honda et al. (62), it is known that Ni is related to the pigment of chicken feathers, which makes sense because most of the chickens used for our analysis had a black feather colour. The average level of the $\mathrm{Ni}$ concentration in feathers shows a wide range depending on the country in which the study was done. For example, a study conducted by Salwa et al. (50) found the average concentration of $\mathrm{Ni}$ to be $1.9-2.7 \mu \mathrm{g} \mathrm{g}^{-1}$. In contrast, a higher $\mathrm{Ni}$ concentration was found in the study conducted by Malik and Zeb (31) in Pakistan, at $7.8-9.0 \mu \mathrm{g} \mathrm{g}^{-1}$, whereas an extremely high concentration of $\mathrm{Ni}$ was observed in the study of Abdullah et al. (56) in Pakistan, at 41.6 - 84.8 $\mu g g^{-1}$.

\section{Copper}

Regarding the $\mathrm{Cu}$ concentration in the chicken feathers, average concentrations of $25.0 \mu \mathrm{g} \mathrm{g}^{-1}$ for Mitrovica, 22.1 $\mu \mathrm{g} \mathrm{g}^{-1}$ for Obiliq and $27.2 \mu \mathrm{g} \mathrm{g}^{-1}$ for the Dragash region were determined. Statistically significant differences between regions Mitrovica and Obiliq as well between Obiliq and Dragash regions were found $(\mathrm{p}<0.01)$, while no difference was found between the Mitrovica and the Dragash regions $(\mathrm{p}>0.05)$. The Dragash region is located in the Sharr Mountain area, which contains the metals $\mathrm{Cr}$ and $\mathrm{Cu}$ (44). Our study results were comparable to study results obtained by other authors, including levels of $10.4 \mu \mathrm{g} \mathrm{g}^{-1}$ (48), 17.0 $\mu g \mathrm{~g}^{-1}$ (63), and $6.60 \mu \mathrm{g} \mathrm{g}^{-1}$ (50). In the study conducted by Dauwe et al. (51) in Belgium, higher $\mathrm{Cu}$ concentration in poultry feathers of $69-88 \mu \mathrm{g}$ $\mathrm{g}^{-1}$ were reported. In contrast, Malik and Zeb (31) in Pakistan found a lower amount of $\mathrm{Cu}$ in poultry feathers at $3.7-4 \mu g g^{-1}$. 


\section{Cadmium}

Cadmium is a non-essential metal for living organisms (64). In our study, the average concentrations of $\mathrm{Cd}$ in chicken feathers were as follows: $12.3 \mu \mathrm{g} \mathrm{g}^{-1}$ in Mitrovica, $11.7 \mu \mathrm{g} \mathrm{g}^{-1}$ in Obiliq and $11.1 \mu \mathrm{g} \mathrm{g}^{-1}$ in the Dragash region. Significant differences in $\mathrm{Cd}$ levels were determined between the regions of Mitrovica and Obiliq and of Mitrovica and Dragash $(\mathrm{p}<0.05)$. However, there were no significant difference between Obiliq and Dragash regions $(\mathrm{p}>0.05)$. The results regarding the presence of $\mathrm{Cd}$ in feathers are similar to results from researchers in other countries, such as Belgium (51) and Pakistan (56). Our results from the Mitrovica region were also comparable to the results of Zogaj and Düring (65), who confirmed the presence of $\mathrm{Cd}$ in various samples from soil, plants, etc.

\section{Zinc}

Zinc is an essential metal (66), and the average concentration of $\mathrm{Zn}$ in chicken feathers in the Mitrovica region was $111.0 \mu \mathrm{g} \mathrm{g} \mathrm{g}^{-1}$. A similar concentration was also observed in the Obiliq region at $109.0 \mu \mathrm{g} \mathrm{g} \mathrm{g}^{-1}$, while a substantially higher concentration was found in the Dragash region at $131.0 \mu \mathrm{g} \mathrm{g}^{-1}$. The presence of $\mathrm{Zn}$ in the chicken feathers in the Dragash region was higher compared to the other regions, in which more non-essential metals $(\mathrm{Pb}, \mathrm{As}$, etc.) were present.

The average concentration of $\mathrm{Zn}$ was shown to be significantly different between the Obiliq and Dragash regions $(p<0.01)$. Statistically significant differences were also found between the Mitrovica and Dragash regions $(\mathrm{p}<0.05)$, whereas the $\mathrm{Zn}$ concentration in chicken feathers did not differ between the Mitrovica and Obiliq regions ( $p>0.05)$. Comparable results were obtained in the study conducted by Salwa et al. (50) who studied the $\mathrm{Zn}$ concentration in chicken feathers in 2012 in Malesia $\left(104.0 \mu \mathrm{g} \mathrm{g}^{-1}\right)$. The $\mathrm{Zn}$ concentration in the feathers of other birds in a study by Jungsoo and Tae-Hoe (48) in Korea, varied between $67.9-103 \mu \mathrm{g} \mathrm{g}{ }^{-1}$, while the study results presented by Malik and Zeb (31) from Pakistan, showed a concentration of $\mathrm{Zn}$ in the range of $133.8-155.2 \mu \mathrm{g} \mathrm{g}^{-1}$. A considerably greater concentration of $\mathrm{Zn}$ in bird feathers was found in the results presented by Abdullah et al. (56) in Pakistan at $226-529 \mu \mathrm{g} \mathrm{g}^{-1}$.
These results support the concept that nonessential metals can have high affinity for sulfhydryl groups and can bind to reduced cysteines in peptides and proteins $(67,68,69,70)$. The current findings also support the data obtained by other researchers related to environmental pollution with metals and their effects on living organisms in the regions of Mitrovica and Obiliq $(40,65,71)$.

\section{Conclusions}

Our investigation detected high levels of metals in chicken feathers in three studied regions of Kosovo (Mitrovica, Obiliq and Dragash). The outcomes of this research clearly show that the region most polluted by metals was the Mitrovica region, with $\mathrm{Pb}$ as the primary metal followed by $\mathrm{Cd}$ and As. In the Mitrovica region, $\mathrm{Zn}$ was identified as the primary non-essential metal. After the Mitrovica region, the most polluted region was Obiliq, where the primary metal was Cd followed by $\mathrm{Pb}$ and As. In Obiliq, we also found higher concentrations of $\mathrm{Zn}$ than other non-essential metals. Dragash was the region with the lowest levels of non-essential metals, and among the essential metals, $\mathrm{Zn}$ was found at the highest concentrations followed by $\mathrm{Mn}, \mathrm{Cu}, \mathrm{Cr}$ and Ni. The most polluted region was Mitrovica, followed by Obiliq, and the least polluted region was Dragash.

Using avian feathers to determine the degree of environmental pollution is a reliable approach for biomonitoring, as shown by numerous researchers from different countries. Based on our results, monitoring of metals in the feathers of chickens can serve as a valuable method for the evaluation of the environmental pollution. Conducting similar surveys in the future could contribute towards the management of environmental pollution, which would promote the health of all living organisms as well as overall public health.

\section{Acknowledgement}

The authors would like to thank prof. John G. McNamara, $\mathrm{PhD}$ for proofreading of this paper.

\section{References}

1. Chowdhury BA, Chandra RK. Biological and health implications of toxic heavy metal and essential trace element interaction. Prog Food Nutr 
Sci 1987; 11: 55-113.

2. He ZL, Yang XE, Stoffella PJ. Trace elements in agroecosystems and impacts on the environment. J Trace Elem Med Biol 2005; 19: 125-40. https://doi.org/10.1016/j.jtemb.2005.02.010

3. Tamás MJ, Martinoia E. Molecular biology of metal homeostasis and detoxification: from microbes to man. Berlin; Heidelberg : Springer Verlag, 2006.

4. Čelechovská O, Malota L, Zima S. Entry of heavy metals into food chains: a 20-year comparison study in Northern Moravia (Czech Republic) Acta Vet Brno 2008; 77: 645-52. https://doi. org/10.2754/avb200877040645

5. Haziri I, Haziri A, Ozuni E, Mehmeti I. Dynamics of malondialdehyde depending on Cd concentration and their relation with the daily weight gain on the chicken hybrid. Asian J Anim Vet Adv 2017; 12: 38-43. doi:10.3923/ajava.2017.38.43.

6. Florea AM, Busselberg D. Occurrence, use and potential toxic effects of metals and metal compounds. Biometals 2006; 19: 419-27. doi:10.1007/s10534-005-4451-x.

7. Filippo CD, Cuzzocrea S, Rossi F, Marfella R, D'Amico M. Oxidative stress as the leading cause of acute myocardial infarction in diabetics. Cardiovasc Drug Rev 2006; 24: 77-87. doi:10.1111/ j.1527-3466.2006.00077.x.

8. Agrawal A, Apnte-Mellado A, Premkumar JB, Shaman A, Gupta S. The effects of oxidative stress on female reproduction: a review. Reprod Biol Endocrinol 2012; 10: e49 (1-31). https://doi. org/10.1186/1477-7827-10-49.

9. Sosa V, Molinéa T, Somoza R, Paciucci R, Kondohc H, Matilde Ell. Oxidative stress and cancer: an overview. Ageing Res Rev 2013; 12: 37690. doi:10.1016/j.arr.2012.10.004.

10. Haziri I, Rama A, Latifi F, Beqiraj-Kalamishi D, Mehmeti I, Haziri A. Effect of different cadmium concentration on some biochemical parameters in "Isa Brown" hybrid chicken. Chemistry 2017; 26: 763-72.

11. Pott U, Turpin DH. Assessment of atmospheric heavy metals by moss monitoring with Isothecium stoloniferum brid, in the Fraser Valley, B.C., Canada. Water Air Soil Pollut 1998; 101: 25-44. doi:10.1023/A:1004916110857.

12. Gerdol R, Bragazza L, Marchesini R, et al. Monitoring of heavy metal deposition in Northern Italy by moss analysis. Environ Pollut 2000; 108: 201-8. https://doi.org/10.1016/S02697491(99)00189-X
13. AksoyA, Özutü MA. Nerium oleander L. as a biomonitor of $\mathrm{Pb}$ and other heavy metal pollution in Mediterranean environments. Sci Total Environ 1997; 205: 145-50. doi:10.1016/S00489697(97)00195-2.

14. Bonada N, Prat N, Resh VH, Statzner B. Developments in aquatic insect biomonitoring: a comparative analysis of recent approaches. Annu Rev Entomol 2006; 51: 495-523. https://doi. org/10.1146/annurev.ento.51.110104.151124

15. Cherry DS, Carins J. Biological monitoring part V: preference and avoidance studies. Water Res 1982; 16: 263-301.

16. Latifi F, Haziri I, Rama A, Musa F, Haziri A, Sinani A. Assessment of heavy metal contamination in some organs of the common carp growing in lakes in Kosovo. Veterinaria (Sarajevo) 2017; 66: 139-44.

17. Rombola P, Battisti S, Scaramozzino P. Animal biomonitoring and micropollutants in public health: review. Epidemiol Prev 2012; 36: 5-14.

18. Erwin M, Custer TW. Herons as indicators. In: Kushlan JA, Hafner H, eds. Heron conservation. San Diego: Academic Press, 2000: 310-30.

19. Demirbass A. Proximate and heavy metal composition in chicken meat and tissues. Food Chem 1999; 67: 27-31. https://doi.org/10.1016/ S0308-8146(99)00103-X

20. Mariam I, Iqbal S, Nagra SA. Distribution of some trace and macro minerals in beef, mutton and poultry. Int J Agric Biol 2004; 6: 816-20.

21. Rama A, Bakalli RI, Mulabegovic N, Selimi Q, Hulaj B, Kastrati R. Lead accumulation in laying hens fed automotive waste oil. In: Annual Meeting of International Poultry Scientific Forum. Atlanta : International Poultry Scientific Forum, 2006: 195, poster S-P161

22. Iwegbue CMA, Nwajei GE, Iyoha EH. Heavy metal residues of chicken meat and gizzard and turkey meat consumed in southern Nigeria. Bulg J Vet Med 2008; 11: 275-80.

23. Carneiro M, Colaço B, BrandãoR, et al. Biomonitoring of heavy metals $(\mathrm{Cd}, \mathrm{Hg}$ and $\mathrm{Pb})$ and metalloid (As) with the Portuguese common buzzard (Buteo buteo). Environ Monit Assess 2014; 186: 7011-21. doi:10.1007/s10661-014-3906-3.

24. Burger J, Gochfeld M. Biomonitoring of heavy metals in the pacific basin using avian feathers. Environ Toxicol Chem 1995; 14: 1233-9. doi: $10.1002 /$ etc. 5620140716

25. Jaspers V, Dauwe T, Pinxten R, Bervoest L, Blust R, Ens M. The importance of exogenous con- 
tamination on heavy metal levels in bird feathers experiment with free living great tits, Parus major. J Environ Monit 2004; 6: 356-60. doi:10.1039/ b314919f.

26. Kim J, Koo TH. The use of feathers to monitor heavy metal contamination in Herons, Korea. Arch Environ Contam Toxicol 2007; 53: 435-41. doi:10.1007/s00244-006-0196-y.

27. Markowski M, Kaliński A, Skwarska J, et al. Avian feathers as bioindicators of the exposure to heavy metal contamination of food. Bull Environ Contam Toxicol 2013; 92: 3302-5. doi:10.1007/ s00128-013-1065-9.

28. Burger J. Metals in avian feathers bioindicators of environmental pollution. Rev Environ Contam Toxicol 1993; 5: 203-311.

29. Monteiro LR. Seabirds as monitors of mercury in the marine environment. Water Air Soil Pollut 1995; 80: 851-70. doi:10.1007/BF01189736.

30. Braune BM, Gaskin DE. Mercury levels in Bonaparte's gull (Larus philadelphia) during autumn moult in the Quoddy region, New Brunswick, Canada. Arch Environ Contam Toxicol 1987; 16: 539-49. doi:10.1007/BF01055810.

31. Malik RN, Zeb N. Assessment of environmental contamination using feathers of Bubulcus ibis L., as a biomonitor of heavy metal pollution, Pakistan. Ecotoxicology 2009; 18: 522-36. doi: 10.1007/s 10646-009-0310-9.

32. Lewis SA, Furness RW. Mercury accumulation and excretion by laboratory reared black-headed gulls (Larus ridibundus) chicks. Arch Environ Contam Toxicol 1991; 21: 316-20. doi:10.1007/BF01055352.

33. Zamani-Ahmadmahmoodi R, Esmaili-Sari A, Savabieasfahani M, Ghasempouri S, Bahramifar N. Mercury pollution in three species of waders from Shadegan. Bull Environ Contam Toxicol 2010; 84: 326-30. doi:10.1007/s00128-010-9933-z.

34. Zogaj M, Paçarizi M, Düring RA. Spatial distribution of heavy metals and assessment of their bioavailability in agricultural soils of Kosovo. Carpath J Earth Environ Sci 2014; 9: 221-30.

35. Nannoni F, Protano G, Riccobono F. Uptake and bioaccumulation of heavy elements by two earthworm species from a smelter contaminated area in northern Kosovo. Soil Biol Biochem 2011; 43: 2359-67. https://doi.org/10.1016/j. soilbio.2011.08.002

36. Millaku L, Imeri R, Trebicka A. Histopathological changes in testes of house sparrow (Passer domesticus). J Mater Environ Sci 2015; 6: 1292-6.
37. DobroshiF, Malollari I, Baruti B, Lajqi N, Salihu D, Kelmendi M. Study on contamination of surface waters in Mitrovica suburban area. J Int Environ Appl Sci 2015; 10: 228-32.

38. Frese SD, Klitgaard R, Pedersen EK. Environmental management in Kosovo: heavy metal emission from Trepca. TekSam Report, 2003/2004: 41-70. https://wiki.rit.edu/download/attachments / 71962211 /Environmental_ management_in.pdf?version $=1$ andmodificationDate $=1317036366967$ andapi $=\mathrm{v} 2$

39. Borgna L, Di Lella LA, Nannoni F, et al. The high contents of $\mathrm{Pb}$ in soils of northern Kosovo. $\mathrm{J}$ Geochem Explor 2009; 101: 137-46. https://doi. org/10.1016/j.gexplo.2008.05.001

40. Veliu A, Syla A. Air pollution with particulate matter and heavy metals of Kosovo: thermal power plant. J Int Environ Appl Sci 2008; 3: 280-7.

41. Prathumratana L, Kim R, Kim KW. Heavy metal contamination of the mining and smelting district in Mitrovica, Kosovo. In: Proceedings of the International Symposia on Geoscience Resources and Environments of Asian Terranes, $4^{\text {th }}$ IGCP and $5^{\text {th }}$ APSEG. Bankok, 2008: 24-6.

42. Thomas L. Coal geology: coal as substance. Chichester : John Wiley and Sons, 1992.

43. Sandroni V, Clare M. Microwave digestion of sediments, soils, and urban particulate matter for trace metal analysis. Talanta 2003; 60: 715-23. https://doi.org/10.1016/S0039-9140(03)00131-0

44. Shabani M, Muqaj B, SukaQ, Frangu S. Genetic zone Sharr Mountains (Kosovo). In: Conference Proceedings of the International Multidisciplinary Scientific Geo Conference. Albena : SGEM, 2011: 367-74. doi:10.5593/SGEM2011/S20.130.

45. Levengood JM. Cd and $\mathrm{Pb}$ in tissues of mallards (Anasplatyrhynchos) and wood ducks (Aix sponsa) using the Illinois River (USA). Environ Pollut 2003; 122: 177-81. https://doi.org/10.1016/ S0269-7491(02)00298-1

46. Zhuang P, Zou B, Lu H, Li Z. Heavy metal concentrations in five tissues of chickens from a mining area. Pol J Environ Stud 2014; 23: 2375-9.

47. DIN-32645. Chemical analysis: decision limit; detection limit and determination limit;

estimation in case of repeatability, terms, methods, evaluation. Alabany : Engineering360, 1994.

48. Jungsoo K, Tae-Hoe K. Heavy metal concentrations in feathers of Korean Shorebirds. Arch Environ Contam Toxicol 2008; 55: 122-8. doi:10.1007/s00244-007-9089-y.

49. Emmanuel TT. Appraisal of $\mathrm{Pb}$ in the or- 
gans and tissues of domestic chicken (Gallus gallus domesticus) in Ibadan. Int J Pure Appl Zool 2016; 4: 225-34.

50. Salwa AA, Shuhaimi-Othman M, Babji A. Assessment of trace metals contents in chicken (Gallus gallus domesticus and quail (Coturnixcoturnix japonica) tissues from Selangor (Malaysia). Int $\mathrm{J}$ Environ Sci Technol 2012; 5: 441-51.

51. DauweT, Lieven B, Ellen J, Rianne P, Ronny B, Marcel E. Great and blue tit feathers as biomonitors for heavy metal pollution. Ecol Indic 2002; 1: 227-34. https://doi.org/10.1016/ S1470-160X(02)00008-0

52. Meehan Sh, Mailman N. Kosovo: lead pollution requires immediate evacuation of Roma camps. London : MAC, Mines and Communities, 2005. http://www.minesandcommunities.org/article. php?a $=1856$ !worddav4088f0b052636cb015f2ea09cfccf7b9.png $\mid$ height=7, width=7! (junij 2019)

53. Kutllovci-Zogaj D, Krasniqi S, Elezaj I, et al. Correlation between blood lead level and hemoglobin level in Mitrovica children. Med Arch 2014; 68: 324-8. doi:10.5455/medarh.2014.68.324-328.

54. Straskraba V, Moran RE. Environmental occurrence and impacts of arsenic at gold mining sites in the western United States. Mine Water Environ 1999; 9: 181-91. doi:10.1007/BF02503691.

55. Janssens E, Dauwe T, Bervoets L, Eens M. Heavy metals and selenium in feathers of great tits (Parus major) along a pollution gradient. Environ Toxicol Chem 200; 20: 2815-20. doi:10.1002/ etc.5620201221.

56. Abdullah M, Fasola M, Muhammad A, et al. Avian feathers as a non-destructive bio-monitoring tool of trace metals signatures: a case study from severely contaminated areas. Chemosphere 2015; 119: 553-61. doi:10.1016/j.chemosphere.2014.06.068.

57. Stafilov T, Aliu M, Sajn R. Arsenic in surface soils affected by mining and metallurgical processing in K. Mitrovica region, Kosovo. Int $\mathrm{J}$ Environ Res Public Health 2010; 7: 4050-61. doi: 10.3390/ijerph7114050.

58. Walter GS. The chromium resources of Albania. Int Geol Rev 1994; 36: 785-95.

http://dx.doi.org/10.1080/00206819409465488

59. Göler D, Bickert M, Doka D. Kromiçanbllokadën - Albanian chromium mining revisited. Die Erde 2015; 146: 271-8. doi:10.12854/erde-146-17.

60. Rizaj M, Beqiri E, McBow I, O’Brien EZ, Kongoli $\mathrm{F}$. The mineral base and productive capacities of metals and non-metals of Kosovo. JOM 2008;
60: 18-22. doi 10.1007/s11837-008-0101-4.

61. Hui CA. Concentrations of chromium, manganese, and lead in air and in avian eggs. Environ Pollut 2002; 120: 201-6. https://doi. org/10.1016/S0269-7491(02)00158-6

62. Honda K, Min B, Tatsukawa R. Distribution of heavy metals, and age-related changes in the eastern great whit egret, Egret alba modesta, in the Korea. Arch Environ Contam Toxicol 1986; 15: 185-97. doi:10.1007/BF01059967.

63. Metcheva R, Yurukova L, Teodorova SE. Biogenic and toxic elements in feathers, eggs, and excreta of Gentoo penguin (Pygoscelis papua ellsworthii) in the Antarctic. Environ Monit Assess 2011; 182: 571-85. doi:10.1007/s10661-011-1898-9.

64. Komarincki GJ. Tissue, sex and age specific accumulation of heavy metals $(\mathrm{Zn}, \mathrm{Cu}, \mathrm{Pb}, \mathrm{Cd})$ by populations of the mole (Talpa europaea L.) in a central urban area. Chemosphere 2000; 41(10): 1593-602. https://doi.org/10.1016/S00456535(00)00018-7

65. Zogaj M, Düring RA. Plant uptake of metals, transfer factors and prediction model for two contaminated regions of Kosovo. J Plant Nutr Soil Sci 2016; 179: 630-40. doi:10.1002/jpln.201600022.

66. Frassinetti S, Bronzetti G, CaltavuturoL, Cini M, Croce CD. The role of zinc in life: a review. J Environ Pathol Toxicol Oncol 2006; 25: 596-610. doi:10.1615/JEnvironPatholToxicolOncol.v25.i3.40.

67. Singh A, Ward OP. Biodegradation and bioremediation. Berlin : Springer, 2004.

(Soil biology series, Vol. 2)

68. Kitchin KT, Wallace K. Arsenite binding to synthetic peptides: the effect of increasing length between two cysteines. J Biochem Mol Toxicol 2006; 20: 35-8. doi:10.1002/jbt.20112.

69. Zhao L, Chen S, Jia L, Shu S, Zhu P, Liu Y. Selectivity of arsenite interaction with zinc finger proteins. Metallomics 2012; 4: 988-94. doi:10.1039/c2mt20090b.

70. Chang YY, KuoTC, Hsu CH, Hou DR, Kao $\mathrm{YH}$, Huang RN. Characterization of the role of protein-cysteine residues in the binding with sodium arsenite. Arch Toxicol 2012; 86: 911-22. doi:10.1007/s00204-012-0828-0.

71. Ferati F, Kerolli-Mustafa M, Kraja-Ylli A. Assessment of heavy metal contamination in water and sediments of Trepça and Sitnica rivers, Kosovo, using pollution indicators and multivariate cluster analysis. Environ Monit Assess 2015; 187: 338. doi: 10.1007/s10661-015-4524-4. 


\title{
OCENA ONESNAŽENOSTIOKOLJAS KOVINAMINA OSNOVI PREISKAVE PRSNIH PERES PIŠČANCEV (Gallus gallus domesticus) V NEKATERIH INDUSTRIJSKIH PODROČJIH KOSOVA
}

\author{
I. Haziri, F. Latifi, A. Rama, M. Zogaj, A. Haziri, H. Aliu, A. Sinani, I. Mehmeti, J. Starič
}

Povzetek: Namen raziskave je bil oceniti prisotnost kovin v treh področjih Kosova s pomočjo piščančjega (Gallus gallus domesticus) perja, vzorčenega v industrijskih področjih Mitrovica in Obiliq ter neindustrijski regiji Dragaš. Raziskava je bila izvedena od septembra do novembra 2016, perje pa je bilo odvzeto 90 piščancem v prosti dvoriščni reji. Koncentracije kovin $v$ piščančjih peresih so bile določene $z$ atomsko absorpcijsko spektrometrijo (AAS). Razpon povprečnih izmerjenih koncentracij kovin ( $\mu \mathrm{g} / \mathrm{g}$ perja) v preiskovanih območjih je bil: Zn 109-131, Mn 6,17-31,30, Cu 22,1-27,2, Cr 5,09-19,0, Ni 12,3-15,8, $\mathrm{Pb}<0,0945-15,5$, Cd 11,1-12,3 in As <0,09-7,44. Najvišje povprečne koncentracije kovin ( $\mu \mathrm{g} / \mathrm{g}$ ) so bile ugotovljene v področjih Dragaš: Zn 131, Cu27,2, Mn 31,3, Cr 19,0, Ni 15,8 in Mitrovica: As 7,44, Cd 12,3, Pb 15,5. Statistično pomembne razlike ( $p<0,001)$ med tremi področji so bile ugotovljene za vsebnost $\mathrm{Pb}, \mathrm{As}, \mathrm{Mn}$ in $\mathrm{Cr}$. Statistično pomembnih razlik nismo ugotovili v vsebnosti Zn med Mitrovico in Obiliqom, v vsebnosti Cu med Mitrovico in Dragašem ter v vsebnosti Cd med Mitrovico in Dragašem. Rezultati raziskave bi morali biti zaskrbljujoči za okolijske agencije na Kosovu in bi jih morali spodbuditi, da sprejmejo konkretne ukrepe, predvsem občasno preverjanje omenjenih onesnaževal v teh industrijskih področjih. Na osnovi naših rezultatov priporočamo spremljanje onesnaženosti okolja s kovinamiz uporabo piščančjega perja kot primernega in uporabnega preskusnega materiala.

KIjučne besede: kovinev sledovih; AAS; piščančje perje; onesnaženost okolja; Kosovo 